\title{
INTENSIVE TEST FOR STUDYING LIPID PEROXIDATION*
}

\author{
J. KOSÁRY**, M. TAKÁCS and I. SIRÓ \\ Department of Applied Chemistry, Faculty of Food Sciences, Szent István University, \\ H-1118 Budapest, Villányi út 31. Hungary
}

(Received: 18 December 2000; accepted: 1 October 2001)

\begin{abstract}
Investigation of lipid peroxidation as a method of quality control in the food industry requires a simple, fast and reproducible method. The preliminary results about an intensive test are presented. Interaction of oil samples and air is intensified by using a piece of filter paper fitting exactly into the bottom of a laboratory vessel as a support. At elevated temperatures $\left(50-55^{\circ} \mathrm{C}\right)$ generated by infrared light the rate of lipid peroxidation is much increased. The test can be carried out in a one-pot-system.

The use of this intensive test is advantageous in studying of the effect of metal salts on lipid peroxidation. It is suggested that this intensive test can be made suitable for the study of different effects and for screening chemical agents, especially that of new antioxidants.
\end{abstract}

Keywords: lipid peroxidation, intensive peroxidaton test, quality control of edible oils, one-pot-system

To reduce lipid-peroxidation leading to rancidity in food and food raw materials stored (NIKI, 1993) in the presence of oxygen, the formation of hydroperoxides, an important step in lipid peroxidation, was investigated. The decomposition of hydroperoxides by a radical mechanism is a complex process that leads to the formation of different shortchain ketones, aldehydes and carboxylic acids with an unpleasant odour or flavour and to dialdehydes, especially malondialdehyde (CECONI, 1993). Lipid peroxidation plays an important role in flavour deterioration and rancidity in food and food raw materials (GUTTERIDGE \& HALLIWELL, 1990).

During our preliminary studies on lipid peroxidation a special ratio called activation coefficient (AC) of the parameters (peroxide value and thiobarbituric acid test) was introduced. AC is the ratio of the value of the given parameter at the time of the measurement and to the value at the beginning of the investigation. Therefore, the higher the $\mathrm{AC}$ value of a particular parameter, the higher is the degree of lipid peroxidation. It was found that $\mathrm{AC}$ values could illustrate changes in the concentration of hydroperoxides and malondialdehyde in stored poppy-seed samples better than the measured data (KOSÁRY \& CSALÁRI, 1998).

\footnotetext{
* Lecture presented at the Károly Vas Memorial Meeting at the Szent István University,

Budapest, 6 September, 2000

** To whom correspondence should be addressed.

Fax: (36)-1-372-6255; E-mail: jkosary@omega.kee.hu
} 
Investigation of lipid peroxidation as a method of quality control in the food industry requires a simple, fast and reproducible method. An efficient method requires making intensive interaction between fats, especially oils and aireal oxygen. From point of view of this interaction there are only a few tests for lipid peroxidation described in the literature (SHIMONI et al., 1994). Most often oil samples are allowed to stand in open vessels or shaken at room temperature or at higher temperature in a thermostat (TOPALLAR et al., 1997). Our preliminary results about an intensive test called intensive peroxidaton test (KOSÁRY et al., 2000) are presented.

\section{Materials and methods}

\subsection{Materials}

Chemicals, $\alpha$-tocopherol and L-ascorbic acid were Sigma products. The complex of Coenzyme $\mathrm{Q}_{10}$ was a gift of BioCo Magyaroszág Kft. Heavy metal salts: copper(II) acetate and cobalt(II) acetate were Aldrich products. The substrate, the freshly pressed and filtered sunflower oil (peroxide value: 0.86) without any food additives, was stored in refrigerator $\left(4^{\circ} \mathrm{C}\right)$ under nitrogen. The original antioxidant content of oil samples was not extracted. For the intensive peroxidation test filter paper (MN 615) and Infrared Rubin electric bulb (Tungsram $250 \mathrm{~W}$ ) were used.

\subsection{Methods}

1.2.1. Intensive peroxidation test. In the intensive peroxidation test the oil $(50 \mathrm{mg})$ was adsorbed to a piece of filter paper $(2 \times 2 \mathrm{~cm})$ fitting exactly into the bottom of a glass laboratory vessel as a support. The elevated temperatures $\left(50-55^{\circ} \mathrm{C}\right)$ were generated by infrared light or thermostat.

1.2.2. Use of heavy metal salts in the intensive peroxidation test. Filter papers were impregnated with different metal salts $(7.6 \mathrm{mmol}$ for $\mathrm{kg}$ of oil) before intensive peroxidation test. The aqueous solutions of the different salts were adsorbed to the filter papers and the wet-papers were dried at room temperature. The salts fixed to the filter papers did not disturb the measurement of peroxide value.

1.2.3. Use of antioxidants in intensive peroxidation test. The solutions of different antioxidants (ethanol for $\alpha$-tocopherol, water for L-ascorbic acid and dichloroethane for the complex of Coenzyme $\mathrm{Q}_{10}$ ) (200 $\mathrm{mg}$ for $\mathrm{kg}$ of oil) were adsorbed to the filter papers or filter papers previously impregnated with different metal salts, and the papers were dried at room temperature.

1.2.4. Measurement of peroxide values. Formation of hydroperoxides in lipid peroxidation of samples was characterized by the peroxide value measured iodometrically according to the literature (DAHLE et al., 1962). The oil sample from the filter paper was extracted with an acetic acid - dichloroethane mixture (1:1) (2 ml) by shaking in the closed vessel for 5 min at room temperature and after removing the filter paper a saturated aqueous potassium iodide solution $(0.10 \mathrm{ml})$ was added. After $15 \mathrm{~min}$ 
the mixture was diluted with water $(7.5 \mathrm{ml})$ and titrated with sodium thiosulfate $(0.005 \mathrm{M})$ in the presence of a starch indicator $(1 \%)$. One unit of peroxide value is defined as the amount $(\mathrm{g})$ of liberated iodine from potassium iodide by sunflower oil $(100 \mathrm{~g})$.

All data are mean values obtained from three replicate experiments.

\section{Results and discussion}

\subsection{Intensive peroxidation tests}

In the intensive peroxidation test the interaction of oil samples and air is intensified by using a piece of filter paper fitting exactly into the bottom of a laboratory vessel as a support. In order to enable extraction of the treated oil with a solvent, one should use a glass vessel, which can be closed during extraction. Thus, test can be carried out in a one-pot-system. Regression analysis was used to determine significant differences in AC values, and coefficients of determination were about 0.8. At room temperature the changes in concentration of hydroperoxides (peroxide values) were more typical of lipid peroxidation than the changes of thiobarbituric assays, therefore only peroxide values were studied in detail. At elevated temperatures $\left(40,50\right.$ and $55^{\circ} \mathrm{C}$ ) generated by infrared light, the rate of lipid peroxidation was much increased.

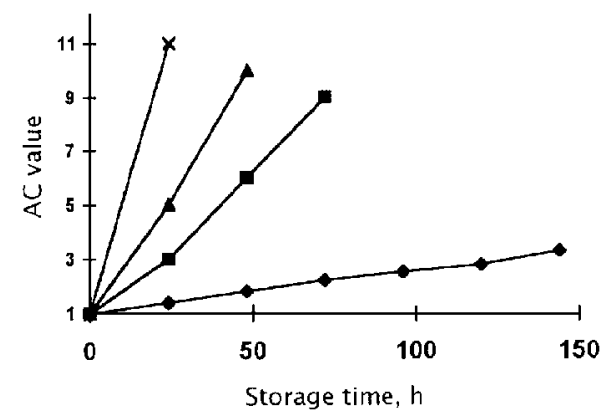

Fig. 1. Change in $\mathrm{AC}$ values of peroxide values with respect to storage time at $23{ }^{\circ} \mathrm{C}(\bullet), 40{ }^{\circ} \mathrm{C}$ $50{ }^{\circ} \mathrm{C}(\boldsymbol{\Delta})$ and $55^{\circ} \mathrm{C}(\times)$ in sunflower oil (elevated temperatures were generated by infrared light)

As this rate can be enhanced also by UV light even at room temperature (MEGURO \& OHRUI, 1996), the treatment of oil samples in thermostat of $55{ }^{\circ} \mathrm{C}$ demonstrated the important role of infrared light in the acceleration of the formation of hydroperoxides. 


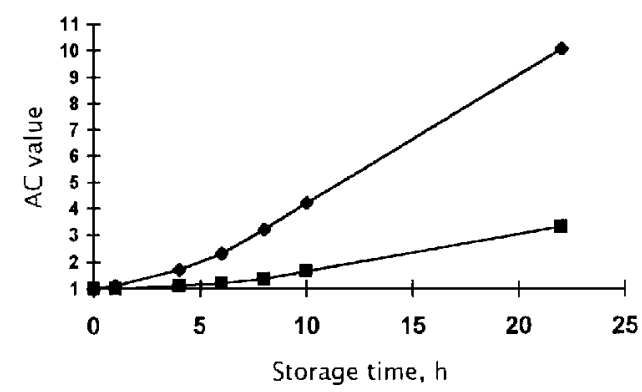

Fig. 2. Change in $\mathrm{AC}$ values of peroxide values with respect to storage time in sunflower oil at $55{ }^{\circ} \mathrm{C}$ generated by infrared light $(\bullet)$ and in thermostat (

\subsection{Effects of accelerators and inhibitors on lipid peroxidation in intensive peroxidation test}

Intensive peroxidaton test made the study of lipid peroxidation possible in a rapid and reproducible way at elevated temperatures, and the time of examination was reduced to about $24 \mathrm{~h}$, therefore the effect of both accelerators and inhibitors of lipid peroxidation was examined.

2.2.1. Effect of metal salts. The filter papers were previously impregnated with different metal salts, and the intensive peroxidaton test proved to be an excellent method for detecting the effects of metal salts on lipid peroxidation. A fast increase of the peroxide values was shown at elevated temperature $\left(55^{\circ} \mathrm{C}\right)$. In the case of cupric and cobalt salts this increase was drastic in the first hours of the test. The difference between the use of infrared light and thermostat was also detected.

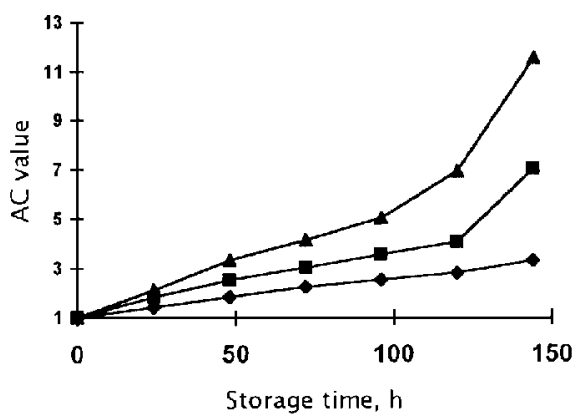

Fig. 3. Change in $\mathrm{AC}$ values of peroxide values with respect to storage time in sunflower oil in the presence of cobalt and copper salt $\left(7.6 \mathrm{mmol} \mathrm{kg}{ }^{-1}\right.$ oil $)$ at room temperature $\left(23^{\circ} \mathrm{C}\right)$. $\bullet$ : Oil; $\mathbf{\square}$ : cobalt + oil;

A : copper + oil 


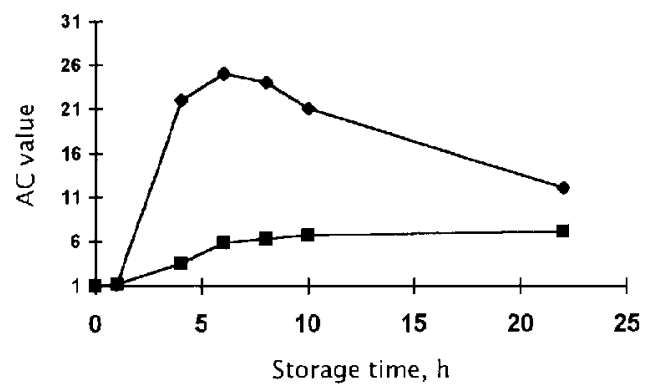

Fig. 4. Change in $\mathrm{AC}$ values of peroxide values with respect to storage time in sunflower oil in the presence of cobalt salt $\left(7.6 \mathrm{mmol} \mathrm{kg}{ }^{-1}\right.$ oil $)$ at $55^{\circ} \mathrm{C}$ generated by infrared light $(\bullet)$, in thermostat (

2.2.2. Effect of antioxidants on lipid peroxidation induced by metal salts. As it was possible to impregnate the filter paper with different antioxidants, it was supposed that the combination of the intensive peroxidation test and metal salts, especially cupric or cobalt salts, could be used for the examination of antioxidants.

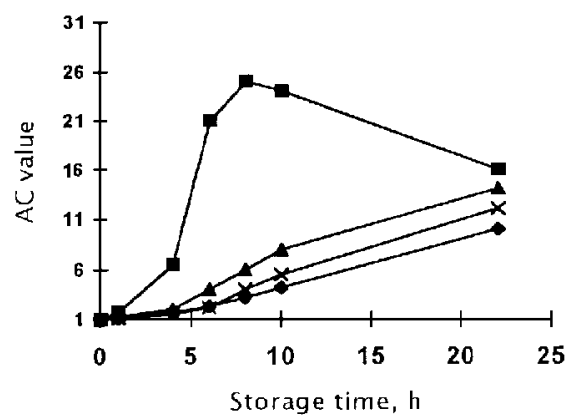

Fig. 5. Change in $\mathrm{AC}$ values of peroxide values with respect to storage time in sunflower oil in the presence of copper salt (7.6 mmol kg-1 oil) and $\alpha$-tocopherol (vitamin E) or the complex of Coenzyme $\mathrm{Q}_{10}$ $\left(200 \mathrm{mg} \mathrm{kg}^{-1}\right.$ oil $)$ at $55^{\circ} \mathrm{C}$ (generated by infrared light). $\bullet$ Oil; $\mathbf{\square}$ : copper + oil; $\boldsymbol{\Lambda}$ : copper + oil + $\alpha$-tocopherol (vitamin E); $\times$ : copper + oil + Coenzyme $\mathrm{Q}_{10}$

This method was found successful in detecting the antioxidant activity of $\alpha$ tocopherol and L-ascorbic acid, therefore the complex of Coenzyme $\mathrm{Q}_{10}$ as a new antioxidant was examined. Coenzyme $\mathrm{Q}_{10}$ is a known antioxidant in vivo (LENCZ, 1985) but it has not been tested for lipid peroxidation of oils in vitro. Our method was found suitable for the detection of the heat inactivation of L-ascorbic acid and also that of the long and strong antioxidant effect of $\alpha$-tocopherol and the complex of Coenzyme $Q_{10}$. 


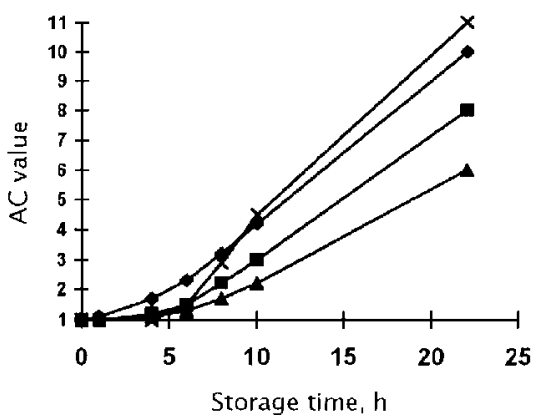

Fig. 6. Change in $\mathrm{AC}$ values of peroxide values with respect to storage time in sunflower oil in the presence of $\alpha$-tocopherol (vitamin E) $\left(200 \mathrm{mg} \mathrm{kg}^{-1}\right.$ oil), the complex of Coenzyme $\mathrm{Q}_{10}$ or L-ascorbic acid (vitamin C)

(200 $\mathrm{mg} \mathrm{kg}^{-1}$ oil) at $55^{\circ} \mathrm{C}$ (generated by infrared light). $\bullet$ : Oil; $\mathbf{\square}$ : oil $+\alpha$-tocopherol (vitamin E);

- : oil + Coenzyme $\mathrm{Q}_{10} ; \times$ : oil + L-ascorbic acid (vitamin C)

Thanks are due to BioCo Magyarország Kft for the complex of Coenzyme $\mathrm{Q}_{10}$.

\section{References}

CECONI, C. (1993): TBA test and "free MDA" assay in evaluation of lipid peroxidation and oxidative stress in tissue systems. Am. J. Physiol., 265, H1031-H1032.

DAHLE, L. K., HiLl, E. G. \& Holman, R. T. (1962): The thiobarbituric acid reaction and autoxidations of polyunsaturated fatty acid methyl esters. Arch. Biochem. Biophys., 98, 253-261.

GutTERidGE, J. M. C. \& HALliwell, B. (1990): The measurement and mechanism of lipid peroxidation in biological systems. TIBS, 15, 129-135.

KosÁRY, J. \& CSALÁRI, J. (1998): A mák avasodásának vizsgálata biokémiai módszerekkel. (Studies on rancidification of poppy-seed by biochemical methods). Olaj, Szappan, Kozmetika, 47, 49-53.

KosÁRY, J., TAKÁCS, M. \& SIRÓ, I. (2000): Az olajok lipid-peroxidációjának vizsgálata intenzív peroxidációs teszttel (IPT). (Study of lipid peroxidation of oils by intensive peroxidation test IPT.) Olaj, Szappan, Kozmetika, 49, 49-53.

LENCZ, G. (1985): Coenzyme Q, a biochemical rationale for the therapeutic effects of Coenzyme Q. Wiley, Chichester, pp. 86-88.

Meguro, H. \& OHRUI, H (1996): Strategy and design of novel reagents for the fluorometric analysis of biomolecules. Biosci. Biotechol. Biochem., 60, 1919-1924.

NikI, E. (1993): Formations and reactions of peroxides in biological systems. -in: PATAI, S. (Ed.) The chemistry of hydroxyl, ether and peroxide groups. Supplement E. Vol. 2, John Wiley \& Sons Ltd., Chichester, pp. 917-936.

Shimoni, E., Armon, R. \& NeEman, I. (1994): Antioxidant properties of Deferoxamine. J. Am. Oil Chem. Soc., 71, 207-211.

TOPALLAR, H., BAYRAK, Y. \& ISCAN, M. (1997): A kinetic study on the autooxidation of sunflowerseed oil. J. Am. Oil Chem. Soc., 74, 1323-1327. 